\author{
ОСОБЛИВОСТІ ОБЛІКУ ТА КОНТРОЛЮ ТОВАРНИХ ОПЕРАЦІЙ \\ ФАРМАЦЕВТИЧНОЇ ГАЛУЗІ В УКРАЇНІ
}

\title{
PECULIARITIES OF ACCOUNTING AND CONTROL OF GOODS OPERATIONS OF PHARMACEUTICAL SECTOR IN UKRAINE
}

УДК 615.12:339.162

https://doi.org/10.32843/infrastruct41-49

\section{Кудирко О.М.}

к.е.н., доцент каредри обліку

та оподаткування

Вінницький торговельно-економічний інститут

Київського національного торговельноекономічного університету

\section{Kudyrko Olena}

Vinnytsia Institute of Trade

and Economics

Kyiv National University of Trade

and Economics

\begin{abstract}
у статті розглянуто особливості обліку товарних операчій фрармачевтичної галузі в Україні. Зазначено основні завдання обліку. Описано та проаналізовано повний життевий цикл товарів із моменту надходження в аптечний пункт до моменту їх вибуття шляхом реалізації покупцю чи списання. Описано схему подання облікової інформації. Розглянуто типову кореспонденцію товарних операцій фрармацевтичної галузі. Висвітлено вимоги щодо умов зберігання лікарських препаратів та медикаментів. Зазначено основні завдання контролю та його значимість. Запропоновано та обірунтовано необхідність запровадження в аптеках системи внутрішнього контролю. Розглянуто необхідність проведення в аптеках та аптечних пунктах, де проводиться реалізація виготовлених за рецептами препаратів, періодичного внутрішнього контролю на відповідність виготовлених ліків. Описано особливості здійснення контролю товарних операцій фрармацевтичної галузі в Україні. Ключові слова: аптека, облік товарів, надходження товарів, вибуття, чіна, медикаменти, документообіг, реалізація товарів, лікарські засоби, контрольні процедури.
\end{abstract}

B статье рассмотрены особенности учета товарных операций фрармацевти- ческой отрасли в Украине. Указаны основные задачи учета. Описаны и проанализированы полный жизненный чикл товаров с момента поступления в аптечный пункт до момента их выбытия путем реализации покупателю или списания. Описаны схему представления учетной информации. Рассмотрены типовую корреспонденцию товарных операций фрармацевтической отрасли. Освещены требования к условиям хранения лекарственных препаратов и медикаментов. Указаны основные задачи контроля и его значимость. Предложено и обосновано необходимость внедрения в аптеках системы внутреннего контроля. Рассмотрена необходимость проведения в аптеках и аптечных пунктах, где проводится реализация изготовленных по рецептам препаратов, периодического внутреннего контроля на соответствие изготовленных лекарств. Описаны особенности осуществления контроля товарных операций фармацевтической отрасли в украине.

Ключевые слова: аптека, учет товаров, поступления товаров, рассход, чена, меди каменты, документооборот, реализация товаров, лекарственные средства, контрольные процедуры.

The article deals with the peculiarities of accounting of commodity operations of the pharmaceutical industry in Ukraine and their significant importance in the market. Pharmacy development is driven by market relationships that form the link between active participants, namely the pharmacy and the drug consumer. It is determined that the main task of the pharmacy is to trade medicines, medicines and other goods in the pharmacy assortment. The complete life cycle of the goods from receipt to the pharmacy points until their disposal by sale to the buyer or write-off is described and analyzed. Of paramount importance are the operations of receipt and production of goods in drugstores. The process of receiving medication at the pharmacy requires monitoring the fulfillment of the obligations specified in the contract and compliance with the delivery time. The system of requirements for storage conditions of medicines and medicines is explained. The theoretical on practical justification of the basics of accounting of commodity operations of the pharmaceutical industry was considered. Accounting is directly related to control, they complement each other. While accounting data performs informational, controlling and analytical functions, they are the basis for the analysis used for control. The main tasks of control and its importance are stated. The specific methods that should be followed at the time of control measures in pharmacies and drugstores where the sale of prescription drugs is carried out are suggested. Namely, it is advisable to introduce into the internal control system periodic checks for compliance of manufactured medicines with prescriptions. Such control should be exercised by the individual responsible person. For this purpose, it is necessary to carry out the analysis of manufactured preparations. Enhanced internal control over the manufacture of medicines will help to use resources rationally. An important prerequisite is that such internal control is present in every pharmacy. In addition, it is possible to note the relevance of the article, confirming the scientific works of many domestic scientists involved in the study of this topic.

Key words: pharmacy, accounting of goods, receipt of goods, disposal, price, medicines, document management, sale of goods, medicines, control procedures.

Постановка проблеми. Торгівля фрармацевтичною продукцією $є$ невід'ємною частиною економіки країни, тому постійний розвиток та удосконалення методики обліку даної галузі $€$ надзвичайно важливим. Динамічне зростання попиту на лікарські засоби потребує контролю у сфері оптової та роздрібної торгівлі. Необхідність у застосуванні сучасних методів обліку та контролю у фрармацевтичній галузі є вкрай важливим, адже ризиків забагато. Особливої уваги потребують операції 3 виготовлення препаратів, що містять наркотичні елементи у своєму складі.

Аналіз останніх досліджень і публікацій. Вивченням проблемних питань, пов'язаних з обліком та контролем товарних операцій підприємств торгівлі фрармацевтичної галузі займалося багато вчених. Значний внесок у дослідженні обліку та методів контролю товарних операцій зробили такі науковці як: Б.П. Громовик, О.В. Посилкіна, М.І. Небава та інші. 
Постановка завдання. Метою статті є висвітлення значущості обліку, та дотримання його основних принципів. Ознайомлення зі структурою товарних операцій в аптеках та на підприємствах фармацевтичної галузі. Відображення таких операцій в обліку та покращення контролю за товарними операціями роздрібної торгівлі. Крім того, запропоновано використання елементів внутрішньогосподарського контролю, що допоможуть покращити контроль за виготовленням ліків за рецептом.

Виклад основного матеріалу. Обліковий процес складається з таких стадій як: спостереження за процесами та явищами, вимірювання, реєстрація та групування за конкретною системою, узагальнення.

Головними завданнями обліку $є$ обробка та відображення первинних даних, їх систематизація, забезпечення збереження майна підприємства, виявлення можливих резервів збільшення доходу.

В обліку використовуються натуральні, трудові та грошові вимірники. Застосування натуральних вимірників (штуки, грами, літри) має важливий вплив на забезпечення контролю за збереженням матеріальних цінностей. Грошовий вимірник (гривні, копійки) $є$ узагальнюючим, що дозволяє контролювати стан та використання матеріальних та фрінансових ресурсів [6, с. 30].

Існують наступні види подання облікової інформації та звітності у фрармацевтичних фрірмах (рис. 1) [4, с. 126].

Як відображено у схемі, всі види обліку пов'язані між собою. Бухгалтерський облік безпосередньо пов'язаний із контролем. Вони доповнюють один одного. Дані бухгалтерського обліку є основою для аналізу, що використовується у контролі.
Основним видом діяльності аптек є торгівля лікарськими засобами, медикаментами та іншими товарами аптечного асортименту. Роздрібна торгівля лікарськими препаратами передбачає собою діяльність $з$ придбання, зберігання та реалізації готових лікарських препаратів у аптеках та інших структурних підрозділах. Реалізація лікарських засобів не повинна здійснюватись через будь-які інші установи чи організації, крім передбачених ліцензійними умовами ситуацій. Оптова і роздрібна торгівлі лікарськими засобами повинні здійснюватись лише при наявності ліцензії відповідно статті 19 Закону України «Про лікарські засоби».

Закон про лікарські засоби регулює відносини пов'язані із виготовленням, реєстрацією та контролем якості ліків. У ньому зазначено, що лікарський засіб - це речовина або їх комбінація (одного або декількох активних фрармацевтичних інгредієнтів і допоміжних речовин), яка призначена для лікування та профрілактики захворювань у людей, або будь-яка речовина чи їх комбінація (одного або декількох активних фрармацевтичних інгредієнтів та допоміжних речовин), яка може бути призначена для запобігання вагітності, відновлення, корекції або зміни фрізіологічних фрункцій у людини шляхом здійснення фрармакологічної, імунологічної або метаболічної дії або для встановлення медичного діагнозу [3, ст. 2]. Варто зазначити, що лише після обов'язкової державної реєстрації ліки допускаються до застосування в Україні. Крім того, не підлягають реєстрації ліки, які виготовляються в аптечних пунктах за рецептами лікарів із дозволених речовин [3, ст. 9].

Першочергове значення мають операції 3 надходження чи вироблення товарів в аптечних пунктах. Найважливішим обов'язковим документом для постачання лікарських засобів чи препаратів

\begin{tabular}{|c|c|c|c|c|c|}
\hline $\begin{array}{c}\text { Види } \\
\text { обліку та } \\
\text { звітності }\end{array}$ & $\begin{array}{c}\text { Внутрішньо- } \\
\text { господарський } \\
\text { (управлін- } \\
\text { ський) облік }\end{array}$ & $\begin{array}{c}\text { Бухгалтер- } \\
\text { ський } \\
\text { облік }\end{array}$ & $\begin{array}{c}\text { Статис- } \\
\text { тичний } \\
\text { облік і } \\
\text { звітність }\end{array}$ & $\begin{array}{c}\text { Фінансова } \\
\text { звітність }\end{array}$ & $\begin{array}{c}\text { Податкова } \\
\text { звітність }\end{array}$ \\
\hline 13 & 13 & 13 & 15 & $\pi$ & 13 \\
\hline $\begin{array}{c}\text { Регламен- } \\
\text { тація } \\
\text { (Закон } \\
\text { України } \\
\text { «Про } \\
\text { бухгал- } \\
\text { терський } \\
\text { облік та } \\
\text { фінансову } \\
\text { звітність» } \\
\text { та ін.) }\end{array}$ & $\begin{array}{c}\text { Повна } \\
\text { самостійність } \\
\text { підприємства. } \\
\text { Дотримання } \\
\text { загальних } \\
\text { вимог } \\
\text { до } \\
\text { оформлення } \\
\text { первинних } \\
\text { документів }\end{array}$ & $\begin{array}{c}\text { Обов'язко- } \\
\text { вість } \\
\text { ведення } \\
\text { основних } \\
\text { бухгалтер- } \\
\text { ських } \\
\text { документів } \\
\text { за єдиними } \\
\text { правилами } \\
\text { (ст. 6). }\end{array}$ & $\begin{array}{c}\text { Обов’яз- } \\
\text { ковість } \\
\text { заповнен- } \\
\text { ня форм } \\
\text { статистич- } \\
\text { ної } \\
\text { звітності } \\
\text { для } \\
\text { всіх } \\
\text { підпри- } \\
\text { смств }\end{array}$ & $\begin{array}{c}\text { Обов’язко- } \\
\text { вість } \\
\text { заповнен- } \\
\text { ня форм } \\
\text { фінансової } \\
\text { звітності } \\
\text { (ст. } 11) .\end{array}$ & $\begin{array}{c}\text { Жорстка } \\
\text { регламен- } \\
\text { тація } \\
\text { (штрафні } \\
\text { санкції). }\end{array}$ \\
\hline
\end{tabular}

Рис. 1. Схема видів подання облікової інфрормації 
до аптеки $є$ договір. В угоді між продавцем та покупцем зазначено права та обов'язки сторін на рахунок постачання будь-яких видів товарів аптечного асортименту. Перелік товарів, що поставляються, їх кількість та ціна зазначені в специфрікації до договору (контракту). Процес надходження медикаментів до аптеки потребує контролю виконання зобов'язань зазначених у договорі і дотримання термінів поставки [4, с. 148].

На момент прийому товару до аптеки, матеріально відповідальна особа перевіряє кількість товарних одиниць та їх масу. Товар, що було доставлено транспортом з аптечних складів приймає завідувач аптеки або уповноважена особа, та проводиться звірка документальних і фрактичних даних на їх відповідність. Основними супроводжувальними документами на момент прийняття лікарських засобів є: пакувальний лист, товарнотранспортна накладна, податкова накладна. Факт прийому товару підтверджується печаткою аптеки та підписом матеріально відповідальної особи, а на екземплярі який залишиться в аптеці ставиться штамп прийому для того, щоб в подальшому його можна було додати до товарного звіту. Медикаменти та ліки, що приймає матеріально відповідальна особа, перевіряють по кожному найменуванню за кількістю, ціною та вартістю. Продукцію приймають за повної її відповідності стандартам якості, технічним умовам та протоколам аналізів. Необхідно звернути увагу на маркування, термін придатності товару, вміст препарату чи медикаменту. Зокрема, обов'язкова наявність маркування від виробника препарату, його назва, серійний номер та інше.

Згідно Плану рахунків в бухгалтерському обліку надходження та вибуття товарів відображають за кореспонденцією рахунків наведеній у таблиці 1 [1]:

Облік лікарських засобів, що були виготовлені ведуть у журналі обліку лабораторних робіт форма 1 та фрорма 2, де зазначають вартість сировини і матеріалів, вартість виготовлення лікарських та розфасовки засобів згідно до тарифної сітки та вартість готового продукту. На основі таких даних в кінці місяця складається довідка, яку повинна підписати матеріально відповідальна особа та бухгалтер [2].

Зіпсовані ліки, та ті, термін придатності яких минув, повинні бути утилізовані. Фармацевтична продукція потребує належних умов зберігання. Для цього потрібно керуватися стандартами якості та здійснювати усі необхідні заходи. Тому, у суб'єкта підприємницької діяльності має бути стандарт зберігання лікарських препаратів, адже за його наявності можна бути впевненим у якості та ефективності таких препаратів чи засобів. На етикетці зазначають вимоги до товарів і матеріалів, які мають відповідати умовам зберігання в аптеках та аптечних складах. Нормою вважають зберігання в сухому, провітрюваному місці за температурного режиму в межах $15-25^{\circ} \mathrm{C}$; не повинно бути сторонніх запахів та надмірного світла [5].

Всесвітня організація охорони здоров'я розробила настанови та вимоги, які мають виконуватися у фрармацевтичній галузі. Варто зазначити, що ці настанови містить конкретні вимоги до персоналу, приміщення та обладнання фрармацевтичної галузі.

Важливим $€$ ведення та зберігання документів, що супроводжують рух товарних запасів. В інструкції конкретно зазначено процедуру зберігання та переміщення лікарських препаратів та $€$ конкретні норми викладення продукції. Обов'язково мають бути дотримані умови Фармакопеї та чинного законодавства.

Реалізація лікарських засобів громадянам здійснюється за рецептами та без рецептів лікарів. Реалізація в аптеках або аптечних пунктах без рецептів лікарських засобів, які відповідно до вимог нормативно-правових актів повинні відпускатися лише за рецептами лікаря - забороняється. Переліки торгових лікарських засобів, які мають реалізовуватися за рецептами або без рецептів лікарів та порядок їх відпуску встановлено Міністерством охорони здоров'я України. Крім того, заборонено продаж товарів, які не віднесені до лікарських засобів та не зареєстровані на території України.

Крім реалізації, в аптеках обліковують ще документальне списання, що не пов'язане з відпуском товару покупцю. Розхід товару проводиться на господарські потреби, при наданні першої медичної допомоги, при знятті ліків на аналіз (здійснює державна інспекція), при закінченні придатності ліків та за рахунок природної втрати.

Реалізуючи товар до лікувально-профрілактичних установ за умови безготівкового розрахунку, аптеки керуються конкретними вимогами. На наркотичні препарати та спирт етиловий вимоги прописують латинською мовою на окремих проштампованих бланках з печаткою і підписом керівника установи.

Відпускна ціна встановлюється в аптеці згідно до прейскуранту роздрібних цін за кожною назвою. Покупцям товари відпускають після оплати рахунку.

Суми грошових коштів за реалізовані товари, що надійшли, вносять до оборотно-сальдової відомості по рахунках покупців. Заборгованості покупці мають погасити до початку наступного місяця.

За умови, що торгівля в аптеці здійснюється у готівковий або безготівковий спосіб із використанням платіжних карток, обов'язково має застосовуватися реєстратор розрахункових операцій.

Особливої уваги потребують операції з виготовлення лікарських засобів, адже вони мають 
Типова кореспонденція з надходження та вибуття товарів

Таблиця 1

\begin{tabular}{|c|c|c|c|c|}
\hline \multirow{2}{*}{$\begin{array}{l}\text { № } \\
\text { 3/ח }\end{array}$} & \multirow{2}{*}{ Зміст товарної операцій } & \multicolumn{2}{|c|}{ Кореспонденція рахунків } & \multirow{2}{*}{$\begin{array}{l}\text { Підтверджуючі } \\
\text { документи }\end{array}$} \\
\hline & & Дт & KT & \\
\hline 1 & $\begin{array}{l}\text { Оприбутковано лікарські засоби } \\
\text { від постачальників }\end{array}$ & $\begin{array}{c}282 \\
\text { «Товари в торгівлі» }\end{array}$ & $\begin{array}{c}631 \\
\text { «Розрахунки } \\
\text { з вітчизняними } \\
\text { постачальни-ками» } \\
\end{array}$ & $\begin{array}{l}\text { Прибуткова } \\
\text { накладна }\end{array}$ \\
\hline 2 & $\begin{array}{l}\text { Відображено торгову націнку } \\
\text { (різниця між продажною та } \\
\text { купівельною вартістю лікарських } \\
\text { засобів) }\end{array}$ & $\begin{array}{c}282 \\
\text { «Товари в торгівлі» }\end{array}$ & $\begin{array}{c}285 \\
\text { «Торгова націнка» }\end{array}$ & $\begin{array}{l}\text { Бухгалтер-ська } \\
\text { довідка }\end{array}$ \\
\hline 3 & $\begin{array}{l}\text { Відображено податковий кредит } \\
\text { з ПдВ }\end{array}$ & $\begin{array}{c}\text { 641/ПДВ «Розрахунки за } \\
\text { податками» }\end{array}$ & $\begin{array}{c}631 \\
\text { «Розрахунки } 3 \\
\text { вітчизняними } \\
\text { постачальни-ками» }\end{array}$ & $\begin{array}{c}\text { Податкова } \\
\text { накладна }\end{array}$ \\
\hline 4 & \begin{tabular}{|l|} 
Оприбутковано вартість \\
орасувальних робіт, виконаних \\
постачальником, та пакувальні \\
матеріали, в тому числі ПдВ
\end{tabular} & $\begin{array}{c}201 \\
\text { «Сировина і матеріали» }\end{array}$ & $\begin{array}{c}631 \\
\text { «Розрахунки } 3 \\
\text { вітчизняними } \\
\text { постачальниками» }\end{array}$ & $\begin{array}{c}\text { Акт виконаних } \\
\text { робіт, накладна } \\
\text { від постачаль- } \\
\text { ника }\end{array}$ \\
\hline 5 & $\begin{array}{l}\text { Відображено податковий кредит } \\
\text { з ПдВ }\end{array}$ & $\begin{array}{c}\text { 641/ПДВ «Розрахунки } \\
\text { за податками» }\end{array}$ & $\begin{array}{c}631 \\
\text { «Розрахунки } 3 \\
\text { вітчизняними } \\
\text { постачальниками» }\end{array}$ & $\begin{array}{c}\text { Податкова } \\
\text { накладна }\end{array}$ \\
\hline 6 & $\begin{array}{l}\text { Збільшено вартість ліків на } \\
\text { вартість фасувальних робіт і } \\
\text { пакувальних матеріалів }\end{array}$ & $\begin{array}{c}282 \\
\text { «Товари в торгівлі» }\end{array}$ & $\begin{array}{c}201 \\
\text { «Сировина і матеріали» }\end{array}$ & Товарний звіт \\
\hline 7 & $\begin{array}{l}\text { Перераховано постачальникам за } \\
\text { лікарські засоби }\end{array}$ & $\begin{array}{c}631 \\
\text { «Розрахунки } 3 \\
\text { вітчизняними } \\
\text { постачальниками» }\end{array}$ & $\begin{array}{c}311 \\
\text { «Поточні рахунки в } \\
\text { національній валюті» }\end{array}$ & $\begin{array}{c}\text { Прибуткова } \\
\text { накладна, } \\
\text { договір, рахунок- } \\
\text { фрактура }\end{array}$ \\
\hline 8 & $\begin{array}{l}\text { Оплачено транспортні послуги у } \\
\text { тому числі ПДВ }\end{array}$ & $\begin{array}{c}631 \\
\text { «Розрахунки } 3 \\
\text { вітчизняними } \\
\text { постачальниками» } \\
\end{array}$ & $\begin{array}{c}311 \\
\text { «Поточні рахунки в } \\
\text { національній валюті» }\end{array}$ & Рахунок-фрактура \\
\hline 9 & $\begin{array}{l}\text { Списано собівартість реалізованих } \\
\text { фрармацевтичних товарних запасів }\end{array}$ & $\begin{array}{c}902 \\
\text { «Собівартість } \\
\text { реалізованих товарів» }\end{array}$ & $\begin{array}{c}282 \\
\text { «Товари в торгівлі»» }\end{array}$ & $\begin{array}{l}\text { Накладні, товарні } \\
\text { чеки, квитанції }\end{array}$ \\
\hline 10 & $\begin{array}{l}\text { Списано торгову націнку на } \\
\text { реалізований товар }\end{array}$ & $\begin{array}{c}285 \\
\text { «Торгова націнка» }\end{array}$ & 282 «Товари в торгівлі» & $\begin{array}{c}\text { Довідка } \\
\text { бухгалтерії }\end{array}$ \\
\hline 11 & $\begin{array}{l}\text { Зараховано кошти від реалізації } \\
\text { фармацевтичних товарних запасів }\end{array}$ & $\begin{array}{c}301 \\
\text { «Готівка в національній } \\
\text { валюті» }\end{array}$ & $\begin{array}{c}702 \\
\text { «Дохід від реалізації } \\
\text { товарів» }\end{array}$ & $\begin{array}{l}\text { Прибутко-вий } \\
\text { касовий ордер }\end{array}$ \\
\hline 12 & $\begin{array}{l}\text { Відображено суму зобов'язання із } \\
\text { податку на додану вартість }\end{array}$ & $\begin{array}{c}702 \\
\text { «Дохід від реалізації } \\
\text { товарів» }\end{array}$ & $\begin{array}{c}\text { 641/ПДВ «Розрахунки } \\
\text { за податками» }\end{array}$ & $\begin{array}{c}\text { Податкова } \\
\text { накладна }\end{array}$ \\
\hline
\end{tabular}

ризики шахрайства на різних стадіях, від створення до списання їх на витрати. Саме тому необхідно запровадити до системи внутрішнього контролю періодичні перевірки на відповідність виготовлених ліків за рецептами. Такий контроль повинна здійснювати окрема відповідальна особа (контролер-орармацевт). Для цього їй необхідно проводити аналіз виготовлених препаратів. Посилений внутрішній контроль за виготовленням ліків допоможе раціонально використовувати ресурси.

Внутрішньому контролю необхідно перевіряти правильність списання матеріалів, що були використанні за рецептом. Для цього потрібно перевірити чи правильно були складені документи та провести контрольні розрахунки грошових сум, які відносять на витрати. Правильно розрахована сума витрат в майбутньому не призведе до викривлення інорормації в бухгалтерських та податкових звітах. Тому важливо, щоб такий внутрішній контроль був присутній у кожній аптеці.

Утворення ціни на ліки та медикаменти регулюється державою. У національному переліку зазначено граничну надбавку постачальника на основні лікарські засоби та медикаменти. Також, надбавки нараховують на відпускні ціни (з урахуванням податків та зборів). Ліки, що виготовляються на замовлення згідно рецепту складаються 3 вартості матеріалів (компонентів) та суми коштів, що витрачено на їх створення та фрасування. 
Контроль за якістю медикаментів також здійснює держава. Державна інспекція 3 контролю якості відповідно до своїх повноважень слідкує за якістю та безпекою ліків і медичних виробів на всіх етапах їх обігу, особливо під час виробництва, зберігання, переміщення та реалізації, утилізації чи знищення. Крім того на неї покладено обов'язок щодо контролю за дотриманням ліцензійних умов виробництва ліків, оптової та роздрібної торгівлі.

На момент забору ліків держаною інспекцією 3 контролю якості офрормлюється акт (у двох екземплярах), що є причиною для списання ліків. Інші операції здійснюються на основі актів та накладних. «Акт переведення» застосовують на момент переведення товару до іншої облікової групи; «Накладна» використовується на момент повернення товару постачальнику. Всі документи, що реєструють операції зі списання чи вилучення товарів вносяться до витратної частини другого розділу місячного звіту.

На контрольну службу покладено також нагляд за дотриманням загальнообов'язкових стандартів. Якщо було виявлено невідповідність технічним вимогам чи стандартам, в обов'язковому порядку державною інспекцією надаються приписи про усунення порушення. В установленому порядку має бути прийнято рішення про вилучення з обігу та заборона реалізації препаратів, що не відповідають вимогам. Відповідно, складаються протокол про адміністративне порушення передбачене законодавством.

Висновки 3 проведеного дослідження. Враховуючи все вище зазначене можна дійти висновку, що товарні операції є частиною великої цілісної системи, в якій головне значення має система обліку. Варто зазначити те, що контроль присутній на всіх стадіях облікового процесу. Необхідно посилити контрольні заходи на початкових стадіях облікового процесу та надати особливої уваги внутрішньому контролю за виготовленням препаратів за рецептами. Адже виготовлення ліків в аптеках має певні ризики, а саме: неправильне списання вартості виготовлення на витрати; неправильний розрахунок списаних сировини і матеріалів на виготовлення препаратів; не дотримання санітарних вимог. Внутрішньогосподарський контроль має контролювати точність та раціональність використання сировини для виготовлення лікарських препаратів, проводити фрактичні звірки, перевіряти на відповідність рецептам уже виготовлені ліки. Внутрішньогосподарський контроль зменшить ризики виникнення помилок уже на кінцевих стадіях обліку.

Сучасні системи обліку та контролю повинні забезпечувати: якісне та надійне ведення бухгалтерського обліку; контроль несанкціонованого доступу до облікової інфрормації; контроль правильності формування бухгалтерських проводок; контроль повноти і вчасності відображення звітної документації; формування відповідних управлінських рішень. Правильне управління товарними операціями призведе до ефективного функціонування підприємств фрармацевтичної галузі.

\section{БІБЛІОГРАФІЧНИЙ СПИСОК:}

1. Вісник. Офріційно про податки: журнал. Аптеки: вимоги до організації роботи, бухгалтерський та податковий облік, 21 жовтня 2011, № 38-39 URL: http://www.visnuk.com.ua/ua/pubs/id/3567 (дата звернення: 23.03.2020).

2. Вісник. Офріційно про податки: журнал. Роздрібна торгівля лікарськими засобами: особливості обліку, 5 січня 2016, № 5 URL: http://www.visnuk.com.ua/ru/ pubs/id/9382 (дата звернення: 23.03.2020).

3. Закон України «Про лікарські засоби» ст. 2 та ст. 9.

4. Немченко А. С., Основи економіки та системи обліку у фрармації: навчальний посібник. Харків Видавництво НФаУ «Золоті сторінки» 2005, с. 148.

5. Новицька Ю.Є., Науково-практичні підходи до управління фрармацевтичної компанії в умовах менеджменту та якості: авторефрерат. Харків, 2016.

6. Терещук С.І., Новикевич А.М., Чухрай І.Л. Система бухгалтерського обліку в аптеках: навчальний посібник. Вінниця: Нова книга, 2003, с. 30.

\section{REFERENCES:}

1. Visnyk. Ofitsiyno pro podatky: zhurnal. (2011), Apteky: vymohy do orhanizatsiyi roboty, bukhhalters'kyy ta podatkovyy oblik, [Pharmacies: requirements for the organization of work, accounting and tax accounting], № 38-39 Available at: http://www.visnuk.com.ua/ua/ pubs/id/3567 (accessed 23 March 2020).

2. Visnyk. Ofitsiyno pro podatky: zhurnal. (2016), Rozdribna torhivlya likars'kymy zasobamy: osoblyvosti obliku [Retailing of medicines: accounting features], № 5 Available at: http://www.visnuk.com.ua/ru/pubs/ id/9382 (accessed 23 March 2020).

3. Zakon Ukrayiny «Prolikars'ki zasoby» [The Law of Ukraine "On Medicines"] st. 2 ta st. 9.

4. Nemchenko A. S. (2005), Osnovy ekonomiky ta systemy obliku u farmatsiyi: navchal'nyy posibnyk [Fundamentals of economics and accounting systems in pharmacy: a textbook]. Kharkiv: NFaU «Zoloti storinky». (in Ukrainian)

5. Novyts'ka Yu. Ye.(2016), Naukovo-praktychni pidkhody do upravlinnya farmatsevtychnoyi kompaniyi $v$ umovakh menedzhmentu ta yakosti: avtoreferat [Scientific and practical approaches to pharmaceutical company management in terms of management and quality]. Kharkiv.

6. Tereshchuk S.I., Novykevych A.M., Chukhray I.L. (2003), Systema bukhhalters'koho obliku v aptekakh: navchal'nyy posibnyk [Pharmacy accounting system: a textbook]. Vinnytsya: Novaknyha, s. 30.(in Ukrainian) 